\title{
Safevi Dönemi Şiî Ulema ve Velâyet-i Fakih'in Ortaya Çıkışını Hazırlayan Tarihsel Süreç Üzerine
}

\author{
Menderes Kurt*
}

\section{Öz}

16. yüzyıldan 18. yüzyılın başlarına kadar İran coğrafyasında hâkimiyet süren Safevi Devleti'nin şiar edindiği İsnâ Aşeriye Şiiliği'nin bu dönemde geliştirmiş olduğu yeni yorum, bugün İran'daki molla yönetiminin (Velayet-i Fakih) temellerinin atıldığ dönem olmuştur. Şah İsmail'in Şiîliği devletin resmi mezhebi ilan etmesi ve Safevilerin İran'ın dışından Şiî ulema getirmeleri hem Safevi Devleti'nin hem de İran'ın toplumsal-siyasal kaderini değiştirmiştir. Safevi dönemi Şiî Usûlî ve Ahbârî ekolü takip eden ulema arasında meydana gelen tartışmalar, İsnâ Aşeriye Şî̂liğini şekillendirmiş ve Şiî ulemanın Gaib İmam'ın yokluğunda devlet yönetimine talip olmalarına, günlük yaşamı yönlendirme ve dinin gerektirdiği ritüelleri uygulayabilmelerine imkân tanımıştır. Bu çalışma, bugün İran'daki Velâyet-i Fakih yönetiminin temellerinin atıldığ Safeviler dönemi İran'ının Şiîleşmesi, dışarıdan Şiî ulema getirilmesi, Şiî ulemanın siyasi, sosyal ve dini tartışmaları, devlet-ulema ilişkileri, Şiî ulemanın önündeki engelleri kaldırarak güçlenmesi gibi konular çerçevesinde Velayet-i Fakih yönetimini ortaya çıkaran süreci ele almayı amaçlamaktadır.

Anahtar Kelimeler: Safeviler, Şiî Ulema, İsnâ Aşeriye Şiîliği, Usûlî ve Ahbârî Ekol, Gaib İmam, Velâyet-i Fakih

Sakarya Üniversitesi Ortadoğu Enstitüsü Doktora Öğrencisi, kurtmndrs@gmail.com 


\title{
The Safavid Period Shi'i Ulama and the Historical Process Preparing the Emergence of the Vilayat-e Faqih
}

\author{
Menderes Kurt*
}

\begin{abstract}
The new interpretation of the Twelver Shi'ism supported by the Safavid State which dominated Iran from the 15th century until the beginning of the 18th centry, has strengthened the power of the mullah administration in Iran (Vilayat-e Faqih). Shah Ismail's declaration of the Shi'ism as an official sect of the state and the Safevid dynasty's Shi'ite ulama import from outside of Iran have changed both the social and the political destiny of the Safavid state and Iran society. The discussions that took place between the ulema following Shi'a rationalist (Usûli) and traditionalist (Ahbâri) school in the Safavid period, has shaped the Twelver Shi'ism and in the absence of the Gaib Imam, allowed Shi'ite Ulama to serve in the state administration and to intervene more in social and religious matters. This study claims that the foundations of Vilayat-e Faqih were built during the Safavid period. In this framework this work deals with issues such as: The expansion of Shi'ite sect in the Safavid period in Iran, Shi' ite ulama import from outside of Iran, the empowerment of the ulama and involvement in government administration, state-ulama relations, Within the framework of these issues, this study aims to explain the historical process during the Safavid Dynasty that enabled the Vilayat-e Faqih administration to came to power in Iran in 1979.
\end{abstract}

Keywords: Safavid, Shi'ite Ulama, Twelver Shi'ism, Usuli and Ahbari School, Gaib Imam, Vilayat-e Faqih

PhD Student, Middle East Institute, Sakarya University, kurtmndrs@gmail.com 


\section{Giriş}

Bu çalışma, 1979 İran İslam Devrimi sonrası İran Devleti'nin yönetim şekli olarak belirlenen Velâyet-i Fakih'in tarihsel kökenine dair bir tartışma yapmayı amaçlamaktadır. Bu çerçevede özellikle Şiî ulemanın siyasetten uzak durma anlayışını yıkan, ulemanın güç kazanmasını sağlayan Usûlî düşünce ve ulemanın siyaset arenasında görünmesine imkan sağlayan Safevi Devleti'nin rolü üzerinde durulacaktır.1971 tarihinde İmam Humeyni, kaleme aldığı Hükûmet-i İslâmî isimli kitabında monarşiyi İslâm'ın dışında bir olgu olarak zikretmiş, ulemanın yönetime doğrudan dâhil olması ve tüm politik ve sosyal reformlarda rol oynaması gerektiğini ileri sürmüştür. Humeyni, eserinde öncelikle bir İslam Devleti'nin kurulmasının gerekliliğini açıklamaktadır. Bu noktada hâlihazırda mevcut yönetimlerin seküler olduğunu ve asıl olanı-İslâmi olan1- temsil etmediklerini, insanları kötü yola sevk etmek ve günah saçmaktan başka bir işlevlerinin olmad1ğını ifade etmiştir. Bu çerçevede Hz. Peygamber'in bırakmış olduğu yol aynen tatbik edilmeli ve İslâmi şeriat üzere işleyen bir "İslâm Devleti" kurulmalıdır. Bu aşamadan sonra Humeyni, kurulan devlet İslâm Devleti olduğuna göre yönetimin de İslâmi olma gerekliliğine vurgu yaparak, İslâm Devleti'nin yönetim şeklinin nasıl olması gerektiğini ele almaktadır. Ona göre peygamber, kendisinden sonra açık bir şekilde İslâm Devleti'ni yönetmesi için bir vasi tayin ettiğine göre -ki bu peygamberlik görevinin tamamlanması için gereklidir- yönetim şeklinin velâyet ${ }^{l}$ üzere olması şart1 açıktır². Nitekim Şii doktrine göre devlet yönetimi imamlar tarafından yapılmaktadır. Fakat Onikinci İmam Mehdi'nin kaybolması ile birlikte devlet yöneticisi/yönetimine dair bir boşluk doğmuştur. Belli bir süre vekiller tarafindan yönetilen Şiî toplum, Gaybet-i Suğra ile birlikte yöneticisiz kalmıştır . Bu noktada Humeyni, Gaybet-i Suğra'dan sonra ne olacak, Allah'ın hükmü sadece 200 yıl ile mi sinırlıdır, Hz. Mehdi gelene kadar İslâm Devleti nasıl yönetilmeli, mali, idari, sosyal, askeri ve dini konularda

Şia'da velayet kavramı hakkında daha ayrıntılı bilgi için bkz. H. Corbin, "Şiîlikte Velâyet Kavramı", çev. Sabri Hizmetli, AÜIFD, XXVI (1983), 717-726.

2 Şia'da egemenliğin peygamberden sonra nasıl olması gerektiği ve halef/vasi tayin tartışması için bkz. Cansu Kaymal, "Şia'da İmamet Meselesi ve Egemenlik", Bilecik Şeyh Edebali Üniversitesi Sosyal Bilimler Enstitüsü Dergisi 2, sy. 1 (Haziran2017): 175-176, 181-182; Hasan Onat, "Şiî̀ İmâmet Nazariyesi”, AÜIFD 32, (1992): 95-100.

3 Serkan Taflıŏlu, "İran İslam Cumhuriyeti’nde Egemenlik ve Meşrûiyet Kaynağ 'Velâyet-i Fakih'”, Ankara Üniversitesi SBF Dergisi 68, no. 3 (2013), 97. 
hukuk kurallarını kim belirlemeli ve nasıl uygulamalı gibi var olan problemlere işaret eder. Kendisi ortaya koyduğu bu problemleri çözebilecek tek kişi/kurumun İslam Devleti'nin başındaki kişi/yönetim olduğunu belirtir. Fakat bu yönetim monarşi yahut demokrasi -batıl, gasıp, meşru olmayan hükümetler, geçici yönetimler- şeklinde olmayacaktır. Ona göre Gaybet-i Suğra'dan sonra yönetme yetkisi fakihlere geçmiştir ${ }^{4}$. Böylelikle fakihler İslâm şeriatı uyarınca cihad, ganimet taksimi, Cuma namazının kılınması, kaza ve ceza hükümlerinin uygulanması, zekat ve humusun toplanması-ki bu gibi yetkilerin Onikinci imamın gaybetiyle birlikte sâkıt olduğu düşüncesi Şia'da hâkimdi- yetkisine sahip olmuştur. Bu çerçevede Humeyni, özellikle kendisine Müslüman diyen bir kişinin Hz. Peygamber'in bırakt1ğ1 miras olan İslam dinini tam anlamı ile yaşayabilmesi için, İslâmi yönetimin -ki bu velâyettir- başta olduğu bir İslâm Devleti'nde yaşaması gerektiğini savunur. Buda ancak peygamberin açık bir şekilde bırakmış olduğu yönetim sistemi olan velâyete sahip çıkmak ve Gaybet-i Suğra'dan sonra bu yönetimin halefi olan fakihlerin/ulemanın yönetimine boyun eğmek ile mümkün olabilirdi. Bununla birlikte Humeyni, bu gerçeği bilen ama geçici yönetimlerin egemenliği altında yaşamaya devam eden Kum ve Necef ulemasına büyük bir eleştiri getirerek, Velâyet-i Fakih (fakihin tasarruf yetkisi, siyasal anlamda fakihin yönetim yetkisi) yönetim şeklinin tarihsel ve mantıksal gerekliliğini ortaya koyarak, kötülüklerin, günahın ve İslâm dininin virüsleri olan geçici yönetimlere açık bir şekilde muhalefetini ortaya koymuştur5. Böylelikle Humeyni, veliyyü'l-emr olan masum imamların Hz. Peygamber'den devraldıkları velâyeti ve bu velâyet'in gaybet döneminde adil fakihlere intikal ettiğini belirterek, geliştirdiği Velâyet-i Fakih yönetim şeklini, dini ve dünyevi tam bir yönetim yetkisine sahip kılmıştır ${ }^{6}$.

Humeyni'nin monarşiye veya Şiî gelenekte geçici yönetim olarak zikredilen şeye muhalefeti uzun bir tarihsel geleneğe dayanmaktaydı. Öte yandan bu fikrin açık bir şekilde ilan edilmesi büyük bir yenilikti ${ }^{7}$. Bu fikir çerçe-

Taflıŏlu, "İran İslam Cumhuriyeti”, 99.

Bkz. İmam Humeyni, Velâyet-i Fakih: İslam Devleti, İmam Humeyni'nin -ksEserlerini Tanzim ve Yayınlama Müessesesi: http://ankara.icro.ir/uploads/islamic government.pdf

6 İsmail Safa Üstün, "Velâyet-i Fakih", Türkiye Diyanet Vakfi İslâm Ansiklopedisi (DİA), c. 43 (Ankara, TDV Yay., 2013), 19-20.

Ira M. Lapidus, Isslâm Topluları Tarihi: 19. Yüzyıldan Günümüze, 2, (İstanbul: İletişim Yayınlar1, 2010), 56. 
vesinde 1979 tarihinde gerçekleşen İran İslam Devrimi ve Humeyni'nin karizmatik otoritesiyle kurulan Velâyet-i Fakih, Şiî dünya için önemli bir değişimin göstergesi olmuştur. Şiî ulema ilk defa doğrudan yönetime dâhil olmakla birlikte tek yönetim merkezidir. Nikki R. Keddie'nin The Roots of the Ulema's Power in Modern Iran isimli çalışmasında belirttiği gibi Osmanlı ve Mısır'da Sünni ulemanın/fakihlerin gücü azalırken, aynı dönemde Şiî ulemanın gücü artmış ve 1979'da Şiî ulema iktidarı ele geçirmiştir. Bu nasıl mümkün olabilmiştir? Keddie'nin de belirttiği gibi bu olgu bir anda gerçekleşmemiştir ${ }^{8}$. Kökleri Safevi döneminde devlet-ulema ilişkileri ve ulemanın bu dönemdeki fikri tartışmalarının Şiîliğe kazandırdığı yeni anlayış çerçevesinde ortaya çıkmıştır. Özellikle Velâyet-i Fakih düşüncesinin ana damarını oluşturan ulemanın toplumsal-siyasal hayata doğrudan katılımını savunan Usûlî düşüncenin, ulemanın Mehdi'nin gelişine kadar geçici yönetimler ile bağlantı kurmak ve doğrudan toplumsal-siyasal hayata müdahil olmaktan uzak durmasını savunan Ahbârî düşünceye galebe çalması ile mümkün olmuştur. Usûlî düşüncenin taraftarı olan Şiî ulemanın toplumsal-siyasal hayata müdahil olması ve Şiî fıkhını uygulama imkânı bulması ise Safevi Devleti (1501-1736) çatısı altında gerçekleşmiştir. Netice itibariyle Velâyet-i Fakih düşüncesini yaratmış olan usûlî ulema teorik düzeyde olan yönetime müdahil olma düşüncesini Safevi Devleti'nin desteği sayesinde pratiğe geçirme imkânına sahip olmuştur. Böylelikle Safeviler Şiî ulemanın yönetimden uzak durma düşüncesini yıkmaya yardım ederek, Velâyet-i Fakih'i doğuran geleneğin kapısını aralamış oldular. Bu çerçevede Velayet-i Fakih'i anlamak için İsnâ Aşeriye Şiîliği'nin ve ulema/ fakihlerinin İran'da Safevi döneminde geçirdiği değişim iyi analiz edilmelidir.

\section{Safevi Tarikatının Şiîleşmesi}

İsnâ Aşeriye Şiîliğin tarihsel gelişiminde 1501 tarihinde Şiî Safevi hanedanının İran'da hâkimiyet kazanması bir dönüm noktası olmuştur. Şeyh Safiyyüddin (ö. 1334) tarafindan Erdebil'de kurulan Safeviyye tarikatı ilk başlarda normal bir tasavvufî merkez olarak ortaya çıkmıştır9 . Fakat daha

Ayrıntılı bilgi için bkz. Nikki R. Keddie, "The Roots of the Ulema's Power in Modern Iran", Studia Islamica, No. 29 (1969): 31-53.

9 Tufan Gündüz, “Safeviler”, DIA, c. 35 (Ankara, TDV Yay., 2008), 451. 
sonra Erdebil Dergâhı'nın postnişliğine Şeyh Cüneyd (ö. 1460)'in geçmesi ile Safeviyye tarikatı "sofizmden siyasete" doğru bir dönüşüm yaşamıştır. Bununla birlikte Şeyh Cüneyd döneminde tarikatın dönüşümü Sünni kimlikten Şiî kimliğe doğru olmuştur. Ayrıca Cüneyd, tarikat şeyhliğinden öteye geçen ilahi bir sayg1 görmüştür. Safeviyye tarikatına artan ilgi, Cüneyd'in atalarının yolunu tamamen değiştirerek Erdebil Dergâhı'nı politize etmesine neden olmuştur. Şiî yapıya bürünen dergâh, Cüneyd ile askeri bir mahiyet kazanmış ve çevresiyle mücadeleye girmiştir ${ }^{10}$. Cüneyd ile güçlenen Şiîlik, ilahi saygı ve siyasi mücadele gibi olgular ardılları Şeyh Haydar (ö. 1488), Şeyh Sultan Ali (ö. 1494) dönemlerinde de bir miras olarak devam etmiştir. Daha sonra tarikatın postnişliğine Şah İsmail'in oturması hem Erdebil Dergâhı hem de Şiî dünyada büyük bir değişime kap1 aralamıştır. Zorlu bir mücadelenin ardından Şah İsmail, 1501 tarihinde Akkoyunlu Devleti'nin (1340-1514) başkenti Tebriz'i ele geçirmiş ve İsnâ Aşeriye Şiîliğini resmi mezhep olarak ilan etmiştir. İsmail'in Şiîlik anlayışı Ortodoks bir anlayıştan öte daha çok Heteredoks bir anlayışa sahipti. Şah İsmail soyunu Hz. Ali'ye dayandırmakla (İmam Musa el-Kazım üzerinden) birlikte, kendisini Safevi tahtına taşıyan Kızılbaş müritlerinin gizli imamı ve beklenen Mehdi'nin temsilcisi olarak sunmuş. Kızılbaşlar arasında da kabul gören bu görüş Şah'ın aşırı bir şekilde -neredeyse ilahi bir boyutta- yüceltilmesine neden olmuştur ${ }^{11}$. Neticede devlet İsmail'in "ilahi" varlığı ile bütünleşmiştir. Fakat 1514 Çaldıran yenilgisi Şah İsmail'in bu imajını büyük oranda değiştirmiştir.

Yeni kurulan Safevi Devleti, Şah İsmail ve onun Kızılbaş kabileleri üzerindeki hâkimiyeti ile ayakta durmaktayd ${ }^{12}$. Çaldıran yenilgisinin ardından Şah İsmail'in inzivaya çekilmesi, Kızılbaşların ülke yönetiminde daha fazla söz sahibi olmasını sağlamıştır. Özellikle Kızılbaşların kendi aralarındaki mücadelenin devlete zarar vermeye başlaması, Kızılbaşları kontrol atında tutmanın zorluğu, Safevi Şahlarını devlet yönetiminde değişiklikler

10 Şeyh Cüneyd hakkında daha fazla bilgi için bkz. Tahsin Yazıcı, "Cüneyd-i Safevi”, DIA, c. 8, (Ankara, TDV Yay., 1993), 123-124; Mehmet Çelenk, 16-17. Yüzyıllarda Iran'da Şiîliğin Seyri, (Bursa: Emin Yayınları, 2016), 58-74.

11 Ömer Faruk Teber, "XVI. Yüzyılda Kızılbaşlık Farklılaşması”, (Doktora Tezi, Ankara Üniversitesi, 2005), 90-93. Çelenk, Iran'da Şiîliğin Seyri, 91-94.

12 Safevilerin kuruluşunda etkili olan Türk oymaklarına dair geniş bilgi için bkz. Faruk Sümer, Safevi Devletinin Kuruluşu ve Gelişmesinde Anadolu Türklerinin Rolü, (Ankara: Güven Matbaası, 1976). 
yapmaya itmiştir. Kızılbaşların Sûf çevreler ile olan bağlantıları ve Safeviyye tarikatına duyulan sevginin başka bir tarikata yönelebilme ihtimali, Kızılbaşlar karşısında Şah'ın otoritesini destekleyecek yeni bir güç oluşturmanın gerekliliği ortaya çıkmıştır. Nitekim bu güç Kızılbaşlara benzer bir hizip olmanın ötesinde devletin merkezileşmesi ve kurumsallaşmasını destekleyecek ulema gibi bir güç odağı olmalıydı. Özellikle Osmanlı Devleti gibi hukuki ve bürokratik anlamda merkezileşmiş ve kurumsallaşmış bir devlet ile mücadele edildiği düşünüldüğünde, bu güç Safevilerin mücadelede kalmasını sağlayacak ve Osmanlı -Sünni dünya- karşısında propaganda üretecek niteliklere sahip olmalıyd $1^{13}$. Ayrıca çoğunluğun Sünni ${ }^{14}$ nüfustan oluştuğu İran'da Şiî bir devlet kurmak, kökleri zayıf bir yönetim anlamına gelmekteydi. Şah İsmail'in yaptığ fetihler ile bölgeyi cebren Şiîleştirme çabaları olsa da ${ }^{15}$ bu çabanın kurumsallaşması ve ibadet babında kök salması gerekmekteydi. Ayrıca devletin üzerinde inşa edildiği “İsnâ Aşeriye Şiîliği’nin” Şiî ulemanın eliyle güçlendirilmesi ve yaygınlaştırılması bir zorunluluktu. Safeviler bu durumda ülke istikrarının anahtarı olan merkezileşme ve kurumsallaşmayı oluşturacak, dışarıya karşı propaganda üretecek, içeride Şah'ın otoritesini destekleyecek -meşruiyet sağlayacakdini bir kurum oluşturmak şeklinde bir çözüm üretmiştir ${ }^{16}$.

\section{3. İran Dışından Ulema Getirilmesi}

Şah İsmail döneminde başlayan İsnâ Aşeriye Şiîliği'nin resmi mezhep olarak kabulü ve bunun bölgede yaygınlaştırılma politikası büyük oranda K1zılbaşlara dayalı ve heteredoks bir yapı arz etmekteydi. Fakat Şah İsmail'in oğlu Şah Tahmasb (1524-1576) (küçük yaşta tahta geçtiği için şahlığının

13 Bkz. Mehmet Çelenk, "Safevîler Döneminin Şî̂-Sünni İlişkileri Üzerinde Etkisi”, Mezhep Araştırmaları 6/2 (Güz 2013): 63-85. Gülay Karadağ Çınar, "Safevi Devleti'nde Otoritenin Temsilcisi Şahlar ve Şîi Ulemayla İlişkileri”, Iran Çalışmaları Dergisi 1, sy. 1 (2017): 20-23. Moojan Momen, An Introduction to Shi'i Islam, (New York: Yale University Press, 1985), 107.

14 Çelenk, Iran'da Şî̀liğin Seyri, 180-182.

15 Teber, "Kızılbaşlık Farklılaşması", 95-99.

16 Vacih Kevserani, Osmanlı ve Safevîlerde Din-Devlet İlişkisi, çev. Muhlis Canyürek, (İstanbul: Denge Yayınlar1, 1992), 151; Ira M. Lapidus, İslam Toplumları Tarihi: Hz. Muhammed'den 19. Yüzyıla, 1, (İstanbul: İletişim, 2013), 397; Özer Küpeli, OsmanlSafevi Münasebetleri, (İstanbul: Yeditepe Yayınları, 2014). 
ilk on yılında Kızılbaşların mücadelesinin etkisinde kalmıştır ${ }^{17}$ ) Kızılbaşları ilahlaştırmacı, binyılcı-aşırı hareketlerinin imhasına, tarikatların ve popüler derviş grupların kovuşturulmasına ve Sünnilerin Şî̂leştirilmesine yönelik bir politika izlemiştir. Bu dönemde İran'da istenilen şekilde yerleşik bir Oniki İmamcı ulema sınıfı "bulunmadığı" için Safeviler, Oniki İmamc1 Arap merkezlerinden -Necef, Bahreyn ve Güney Lübnan/Cebel-i Amil- ulema davet etmek zorunda kalmıştır ${ }^{18}$. Böylelikle ihtiyaç duyulan tahsilli/medreseli ulemanın dışarıdan ithali ile dini ve kültürel devrimi, merkezileşme ve kurumsallaşmayı gerçekleştirme yoluna gidilmiştir.

Dışarıdan davet edilen ulema ile İran'da Şiîliğin yaygınlaştırılması önemli bir ivme kazanmıştır. Bu dönemde ulema ile devlet (Şah) arasındaki yakınlık ve işbirliği, Şî̂liğin resmi mezhep olarak gücünü artırmıştır. Şah'ın ulemaya bahşettiği güç, Şiî ulemanın yönetimde rol almasına imkân tanımıştır. Bu dönemde dışarıdan getirilen ulema ve devlet münasebetleri sonraki dönemlerde gelişen Merce'iyye müessesesinin ve Velayet-i Fakihle sonuçlanan sürecin oluşmasında köşe taşıdır ${ }^{19}$.

Safevi çağı, ulemanın güç kazandığı ve İmam gibi hareket etmeye cüret ettiği, İmam'ın siyasi otoritesi sanki ulemaya geçmiş gibi davrand1ğ1 (daha önce böyle açık bir çaba yoktur) bir dönemdir. Bu durum ise, toplumun yeniden şekillenmesi için ulemanın pratikte daha aktif olması, yani İmam'ın fonksiyonlarını icra etmesi gerekliliğinden kaynaklanmıştır. Tam olarak İmamlık değil, sadece topluma örnek ve canlı bir liderlik yapmaktan ibarettir bu. Çünkü Şiî dünyada halen “kayıp İmam'ın dönüşü ve meşru bir devletin ortaya çıkacağı” inanışı hâkimdir ${ }^{20}$. İmam'ın dönüşü ve meşru devlet inanışları ulema ve Şah açısından pek çok konunun meşruluğunun sorgulanmasına neden olmuştur. Nitekim Așeriyye Şiîliği'nin imamet doktrini son derece açıktır: İlahi tayin ve nesebî bağlılık. Gaybet-i Suğra döneminde dört sefirin naîbliği, hiç birisinin Ehl-i Beyt'e mensup

17 Tufan Gündüz, “Tahmasb”, DİA, c. 39, (Ankara, TDV Yay., 2010), 413.

18 Farhad Daftary, Şii İslam Tarihi, çev. Ahmet Fethi, (İstanbul: Alfa Tarih, 2016), 109; Şah İsmail ve Tahmasb'ın yaymaya çalıştığı bu mutedil Şî̂lik hususunda çok az malumat sahibi olduğu ve Şî̂liğe dair ulaşılabilen tek kitabın İbn Mutahhar elHillî'nin Kavâidu'l-İslâm” adlı kitabı olduğu rivayet edilir. Bkz. Keddi, "The Roots of the Ulema", 41-42.

19 Mazlum Uyar, Şî̀ Ulemânın Otoritesinin Temelleri, (İstanbul: Kaknüs Yayınlar1, 2004), 108.

20 Uyar, Şiî Ulemâ, 108. 
olmamas1 sebebiyle, tayin ile söz konusu olmuştur. Dört sefirden sonra hiç kimsenin vekillik iddiasında bulunamayacağı da son derece açıtır ${ }^{21}$. Bu nedenle Safevi Şahlarının ilahi tayin iddiasında bulunmaları mümkün değildi. Israrla vurguladıkları ehl-i beyt'e mensubiyet de hakimiyetlerine meşruiyet yaratmaya yönelik bir taktik idi. Şah İsmail'in ehl-i beyt'e mensubiyet iddialarına eleştiri gelmemesinin, bu dönemde İran'da buna karşı argüman ortaya koyabilecek nitelikte ulemanın "olmayışından" kaynaklandığ 1 iddia edilmektedir ${ }^{22}$. Cebel-i Amilden getirilen ulema ile birlikte Safeviler bir nevi imamlık iddialarını da tartışmaya açmış oldular. Devletin Şiî yapısında, Safevi Şahlarının ortada bir ilahî tayin ve nass olmamasından dolayı iktidarlarını nasıl izah edecekleri ve meşruluğu nasıl sağlayacakları çözüm bekleyen problemlerdi ${ }^{23}$. Momen'in belirttiği üzere Şiîlik, Sünni devletlerin içerisinde azınlık kaldığı için erken dönemde Mâverdî $(1058)^{24}$ gibi politik dünyayı dini dünyaya entegre edecek siyasal bir düşünce geliştirememiş ya da geliştirme ihtiyacı hissetmemiştir ${ }^{25}$. Ortaçağda Sünni İslâm fikhı geliştirmiş olduğu siyaset ve meşruiyet nazariyesi ile adil veya zalim olsun İmam'a ve devlet başkanlarına itaatin vacip olduğunu belirtiyordu. Sünni fikhı, devlet başkanı ve İmam'ın seçilmesinde açık bir yol ve yönteme sahipti. Zira en kötü sultanın idaresi anarşi ve kargaşaya tercih edilirdi. Buda Sünni yöneticiler için meşruiyet sorununu büyük

21 İrfan Abdulhamid Fettah, "İmâmiyye Şîa'sında Velâyet-i Fakih, Tarihi Arka Plan”, çev. Seyit Bahcıvan, Marife, sy. 2 (Güz 2009): 243-244. Büveyhiler döneminden itibaren yaşanan gelen velayet, gaib imamın temsili meselesi üzerine tartışmalar için bkz. aynı eser. Ayrıca bkz. Ethem Rûhi Fığlalı, İmâmiyye Şîası,(İstanbul: Ağaç Kitabevi Yayınlar1, 2008).

22 Momen, An Introduction to Shi'i, 108.

23 Momen, An Introduction to Shi' $i$, 108-109.

24 Mâverdî, insanların farklı yaratılışından kaynaklanan tabii eşitsizliklere toplumsal yaşamın getirdiği eşitsizliklerin katılması dolayısıyla çatışmaların olağan olduğunu söyler. Dolayısıyla adaleti, huzuru sağlamak için siyasi bir iktidara ihtiyaç vardır. Fakat onun bu siyasi iktidar anlayışı hem Fars siyaset kültüründeki zıllullah (Allah'ın gölgesi) ideolojisini hem de yanılmaz kanun koyucu (mâsum imam) ve Şiâ'daki imamın nalsa tayini fikrini reddetmektedir. $\mathrm{O}$, gerekli şartlara vakıf olan Müslüman bir kişinin toplumunun siyasi iktidar (halife, imam) ihtiyacına cevap verebileceğini belirtir. Özellikle el-Ahkam-üs-Sultaniyye isimli eseriyle İslam siyaset teorisi geliştirmiştir. Böylelikle Sünni dünyada siyasal iktidarın seçimi, sorumlulukları ve meşruluğu konularına büyük oranda açıklık kazandırmıştır. Ayrıntılı bilgi için bkz. Cengiz Kallek, "Mâverdî”, DİA, c. 28 (Ankara, TDV Yay., 2003), 180-186; Ahmet Güner, "Mâverdî'nin Hilafet Kuramının Tarihsel Arkaplanına Bir Bakış (II)", D.E.Ü. Illahiyat Fakültesi Dergisi, sy. 17 (İzmir, 2003): 227-252.

Momen, An Introduction to Shi'i, 192. 
oranda ortadan kaldırmaktayd $1^{26}$. Sünniliğin ülü'l-emr'e itaat edilmesine yönelik anlayışına karşılık Şî̂ler, yönetme yetkisinin İmam'a ait olduğunu kabul ederlerdi. Nitekim, Onikinci İmam'ın gaybeti ile birlikte, Şiîlerin Gizli İmam'ın ahir zamanda geri döneceği düşüncesi sonucu geliştirdikleri bekleyiş nazariyesi, onları siyaset dünyasından soyutlamış ve toplumsalsiyasal olaylara karşı depolitize bir tavır takınmalarına neden olmuştur ${ }^{27}$. Bu çerçevede, İsnâ Aşeriye Şiîliği üzerinde yükselen Safeviler açısından, Şiî fikhına dayanarak İmam'ın vekilliği iddiasında bulunmasının temelleri bulunmamaktaydı. Şah İsmail meşruluğunun temeli daha çok Şah'ın askeri gücünü oluşturan Kızılbaşlar nezdinde ilahlaştırılmış imajıydı.

Kendisini ilahlaştıran Kızılbaşlardan rahatsız olan Tahmasb ise daha samimidir. Mehdici ve aşırı fikirleri reddederek daha mutedil bir Şii anlayış benimsemiş ve Şiiliğin kurumsallaşması için çaba harcamışıır ${ }^{28}$. Tahmasb bir taraftan devletin kurumsallaşmasına çabalarken diğer taraftan Şiîliğin kurumsallaşması için uğraşmıştır. Fakat Şiîliğin kurumsallaşması için getirmiş olduğu ulemanın sahip olduğu Şiî fıkhında Şah'ın yönetici olarak meşruiyeti de tartışma konusuydu. Öte yandan Sünni-Şî̂ (Osmanl1-Özbek ve Safevi mücadelesi) mücadelesi Tahmasb'ın güçlü propagandacılara ihtiyacı ve ülkenin Şiîleşmesi mevzusundaki aciliyet dolayısıyla dışarıdan getirilen ulema ile çalışmada beis görmemiştir. Ayrıca ülkesinin belli bir düzlemde, belli bir devlet felsefesi içerisinde merkezileşmesi gerekiyordu. Bunun Kızılbaşlar ve Sûfiler ile yapılamayacağı anlaşıldığı için Şah, bu problemleri, hepsine meşruiyet kazandıracak pratik bir Şiî ulema olan Şeyh Ali el-Kerekî el-Amili’ye (ö. 1534) verdiği güç ve görevler ile çözmeye çalışmıştır29 ${ }^{29}$ Cebel-i Amil'den ilk defa Şah İsmail tarafından davet edilen Kerekî, Şah İsmail için Şah, Sultan, İmam gibi unvanların kullanılmasını onaylamış ve bu suretle Oniki İmam vekili makamında bulunduğunu kabul etmiştir. Kerekî, daha sonra imam vekili unvanını dini anlamda kendisine tevcih etmiştir ${ }^{30}$. Kerekî'nin Şah'a tevcih ettiği bu ünvanlar dönemin

Subhi Salih, İslam Kurumları, çev. İbrahim Sarmış, (Ankara: Fecr Yayınevi, 1999), 173-176.

27 Momen, An Introduction to Shi 'i, 192-193; Ahmed el-Kâtib, Şiada Siyasal Düşüncenin Gelişimi: Şûrâdan Velayet-i Fakîhe, (Ankara: Otto Yayınları, 2016), 16.

28 Uyar, Şî̀ Ulemâ, 113.

29 Momen, An Introductionto Shi'i, 110.

30 Çınar, "Şahlar ve Şiî Ulema", 23-24.
} 
Şiî uleması tarafından eleştirilmiş ve tepki ile karşılanmıştır. Tahmasb döneminde ise Şah, devleti kurumsallaştırmak işini Şiî ulema ile yapabileceğinin farkında olduğu için daha nazik bir siyaset izlemiştir. Tahmasb'a Kerekî tarafından taç giydirilmesi ile Şiî ulema dini konuların yanında siyasi bazı konuları da meşrulaştırmaya başlamıştır. Tahmasb bu dönemde yayınladığı iki ferman ile Kerekî’yi "müçtehitlerin sonuncusu/en üstünü” (hatemü'l-müçtehidin), hatta “İmam'1n vekili” (naibü'l-imam) ilan etmiş ve ona ülkede İsnâ Aşeriye Şiîliğini yaygınlaştırılma sorumluluğunu vermiştir $^{31}$. Böylelikle Şahlar İmam'ın vekilliği iddiasından vazgeçerek, meşruiyetlerini kendisi tarafindan desteklenen ulemadan aldığı "en büyük müçtehit'i naibi” sıfatı ile sağlamaya başlamıştır. Neticede, İmam'ın gaybet dönemi "temsilcileri" olmaları nedeniyle, onların sahip olduğu gücün farkında olan Şahlar, ulema ile ilişkilerinde hassas davranmıştır ${ }^{32}$. Fakat bu dönemde mutlak gücün halen Safevi Şahlarına ait olduğunu söylemeliyiz.

Aslında Kerekî, gaybet sırasında “İmam'ın genel vekilliği”- “en-niyâbetü'lâmme/niyâbet-i âmme" fikrini geliştirmiştir ${ }^{33}$. Bu fikre göre ulema, gizli imamın fonksiyonlarını icra edebilir ve Cuma namazı kıldırabilirdi. Kerekî ayrıca ölü müçtehide uymanın cevazına karşı çıkmıştır ${ }^{34}$. Kerekî, Şah tarafindan kendisine verilen yetkiler ile yayınladığ fetvalar sayesinde Safevi iktidarının işini kolaylaştırmıştır. Böylelikle ilk defa Gaib İmam'ın temsil hakk1 Şiî ulemanın uhdesine geçmeye başlamıştır ${ }^{35}$. Kerekî ile başlayan muhacir ulema akını 16. ve 17. yüzyıllarda da devam etmiş̧tir. Bahreyn,

\section{Daftary, Şii İslam Tarihi, 109.}

32 Uyar, Şî̀ Ulemâ, 110.

33 Kerekî’nin bu fikrinin arka planı Muhakkık Hilli (ö. 1277) ve Allâme Hilli (d. 1250) tarafından nispeten geliştirilmiştir. Büveyhi ve İlhanlı döneminde Şiî ulemanın elde ettiği nispeten siyasi güç sayesinde geliştirilmiş içtihat anlayışı sayesinde, Şiî ulemanın imamın otoritesini temsil noktasında önemli bir güç kazanmıştı. Safeviler dönemindeki müçtehitlerin faaliyetleri büyük oranda bu temele ve Hille okulunun geliştirmiş olduğu anlayışa dayanmaktadır. Burada şunu da belirtmek gerekir ki, Şî̂lik mezhebi Safeviler dönemine kadar Sünni mezhebi gibi güçlü bir siyasi güç tarafından desteklenmemiştir. Siyasi gücün yokluğu Şî̂ ulema için imamın temsiliyeti ve devlet yönetiminin meşruluğunu tam anlamı ile ele alınmamasına neden olmuştur. Büveyhiler döneminde nispete geliştirilen imamın genel vekilliği, Safeviler gibi güçlü bir yönetimin desteği sayesinde acil çözülme kavuşturulması gereken bir vaka haline gelmiştir. Bu aciliyet Şiî fikhının da gelişmesine olanak tanımıştır. Bkz. Uyar, Şiî Ulemâ, 72-92; Fettah, "İmâmiyye Şîa's1", 245.

34 Daftary, Şii İslam Tarihi, 110.

35 Çınar, "Şahlar ve Şiî Ulema", 26; Cengiz Kallek, "Sânî Muhakkık-1 Kerekî", DİA, c. 25, (Ankara, TDV Yay., 2002), 280-281. 
Lübnan ve Irak'tan gelen ulema, müftü, imam, müderris, kadılık vb. görevlerde bulunmuş ve devletten yardım almıştır ${ }^{36}$.

\section{Usulî Ekol-Cebel-i Amil Uleması ve Şiî Ulemanın Tartışma Konuları}

Kerekî gibi ulemanın Safeviler ile pratik ilişkiler geliştirmesinde ve Safevi hâkimiyetinde önemli roller almasında Usulî ekolün önemli bir pay1 bulunmaktadır. Onikinci İmam'ın gaybeti ile birlikte Şia içerisinde fikhi ve itikadi problemlerin çözümünde bir takım sıkıntılar ortaya çıkmıştır. Tabi bu belirsiz durum Şiî ulema arasında iki farklı ekolün oluşmasına neden olmuştur. İlki fikhın rasyonel (akla dayanan) metodolojisine karşı çıkarak her dinî hükmün Peygamber'den ve imamlardan gelen hadislerle (haber) desteklenmesi gerektiğini düşünen Ahbârî/Nakilci ekolüdür. İkinci ekol ise fikhın rasyonel metodu savunarak yeni problemler karşısında içtihatta bulunmak gerektiğini savunan Usûlîl/ Içtihadi ekolüdür ${ }^{37}$. Usûlî ekol, zamanın şartlarına göre esneyebilmesi, meşruluğu tartışmalı olan Şah yönetimi ve ulemanın toplumsal-siyasal hayata ki yerini alması gibi konulara daha pragmatik çözümler üretebilmesi nedeniyle Safevi dönemi tercih edilen ekol olmuştur. İstisnaları olmakla birlikte İran'da Ahbârîlik fazla güçlenmemiştir. Nitekim Ahbârîlik marjinal bir statüye düşürülerek İran'ın Hûzistan bölgesinde Arapça konuşan Şiîler arasında kendisine yer bulmuştur ${ }^{38}$.

Usûlî ulemanın etkili olduğu Cebel-i Amil'in coğrafi konumu ve ilmi çevresi, usûlî ekolün Safevi döneminde ön plana çıkmasında önemli bir etken olmuştur. Güney Lübnan'ın iç bölgelerinde yer alan Cebel-i Amil'de yaşayan Şiî ulema, kendilerini bütün Şiî toplumun en tepe noktasına konumlandırmaktaydı. Cebel-i Amil'in uzak ve dağlık bir bölge olması, Şiî geleneğin burada güçlü bir şekilde gelişmesine katkı sağlamıştır. Bununla birlikte Cebel-i Amil, bulunduğu konum itibariyle pek çok Sünni ve Şiî

36 Şî̂ alimler Şeyhü'l-İslâm, camilerde vaiz ve medrese hocaları olarak İran halk1 arasında Şî̂ akide ve pratiğinin ılımlı ve sağlam bir şekilde yayılmasında önemli bir rol üstlenmiştir.

37 Ramazan Tarik, "Şia'da Usulîliğin Doğuşu ve Şeyh Müfid”, Mezhep Araştırmaları 7, sy. 1, (Bahar 2014): 251.

38 Hamid Algar, "İran (III. Kültür ve Medeniyet)", DIA, c. 22, (Ankara, TDV Yay., 2000), 410 . 
âlimin ilişki kurmasına olanak sağlamıştır ${ }^{39}$. Nitekim bölgenin oldukça geçirgen bir yapıya sahip olması, Sünni ve Şiî âlimlerin birbirlerinden ders alabilmesine imkân tanımıştır. Cebel-i Amil'de güçlenen Usûlî ekole mensup Şiî ulema, Sünni ulemayla kurdukları ilişkiler sayesinde Ahbârî ekole karşı farklı bir yorum üretebilme esnekliğine kavuşmuştur. Örneğin Cebel-i Amil'den Şehid-i Evvel olarak bilinen Şemseddin Muhammed b. Mekkî (1333-1384)'nin, Mekke, Medine, Bağdat, Şam ve Kudüs'e gittiği ve kırkın üzerinde Sünni âlimden ders aldığı rivayet edilmektedir. Kendisi usûlî düşünceyi temsil etmektedir ve Şiî geleneğe ek olarak Sünni anlayıştan öğrendikleri temelinde usûlü'l fikhın metot ve kurallarını belirlemiştir ${ }^{40}$. Ayrıca Şehid-i Sani olarak tanınan Zeynuddin b. Nureddin Ali (1506-1558), Cuba'da âlim bir aileden gelmektedir. On altı Sünni âlimden ders aldığı rivayet edilmektedir. Sünni dünyayı dolaşmış ve Osmanlı Devleti tarafından Ba'albek'teki Nuriyye Medresesi'ne tayin edilmiştir. Sünni âlimlerden öğrendiği bilgiler sayesinde hadis rivayeti ile ilgili sistematik bir şekilde eser telif edebilen ilk Şî̂ âlimlerin biri olduğu iddia edilmektedir (İstanbul'da ölmüştür). İran'a gelen Kerekî, Şehid-i Evvel entelektüel çizgisini takip eden âlimlerde ders almıştır. Nitekim Kerekî, Kahire’ye yaptığı bir seyahatinde Sünni âlimlerden tefsir, hadis gibi dersler almıştır. Bunun yanında Ahmed b. Ali el-Amili, Zeynuddin Ca'fer b. Hüsam elAmili gibi Cebel-i Amil'den hocalardan çeşitli dersler almıştır ${ }^{41}$. Böylelikle Kerekî'de usûlî ekolün temel öğretilerine tevarüs etme şansına sahip olmuştur. Kerekî’nin İran'a çağırılmasının sebebinin, Hourani'nin işaret ettiği gibi, şeriatın koruyucusu İmam'ın halefi olarak fakihlerin/ulemanın rolüne vurgu yapan, ulemaya içtihat yapabilme ve geçerli yöntemleri uygulamak suretiyle kaynaklardan hüküm çıkarabilme imkânı veren bir geleneğin temsilcisi olması kuvvetle muhtemeldir ${ }^{42}$. Yani burada pek çok çalışmada Safevilerin dışarıdan Şiî ulema davet etmesinin sebebi olarak gösterilen İran'da "ulema yokluğu” fikrinin yeniden tartışılması gerekmektedir. Kerekî gibi usûli düşünceyi tevarüs etmiş olan ulemanın davet edilmesinin, âlim yokluğundan öte, Safevi Devleti'nin mevcut problemle-

\footnotetext{
39 Albert Hourani, “Cebel-i Amil'den İran'a”, çev. Habib Kartaloğlu, Usûl İslâm Araştırmaları, sy. 23, (Ocak-Haziran 2015), 214, 217.

40 Hourani, “Cebel-i Amil'den İran'a”, 218.

41 Kallek, "Sânî Muhakkık-1 Kerekî”, 180.

42 Hourani, “Cebel-i Amil'den İran'a”, 221.
} 
rine pratik çözüm üretebilecek ulema ihtiyacından kaynaklandığı düşüncesi göz önünde bulundurulması gereken bir başka faktördür. Usûlî ekole mensup ulema, yöneticinin belirlemiş olduğu toprak vergisini (haraç) toplanmasına, ulemanın vergiden kendi paylarını almasına ve hatta İmam'ın yokluğunda ulemanın Cuma namazı kıldırmasına cevaz vermekte bir beis görmemiştir ${ }^{43}$. Bununla birlikte usûlî ekole mensup ulemanın Safeviler ve Şiî fikhına dair en önemli işlevleri, Şia'yı siyasetten soyutlayan bekleyiş nazariyesinden uzaklaştırarak yönetime dâhil etmiş olmasıdır. Safevi dönemi siyasi tecrübesi, kendisinden önce Şia'ya yönetime katılma imkanı sunan Büveyhi ${ }^{44}$, Serbedari, Mar'aşi ve Muşa'şaî gibi önceki siyasi tecrübeden farklı idi. Bu devletlerin hepsi Safeviler gibi ideolojik bir argümana sahip olmayan salt siyasi nitelikteydiler ${ }^{45}$.Safeviler siyasi hakimiyet ile bütünleșen bir İsnâ Aşeriye dini ideolojisinin savunucusu olarak, Şia'y1 bekleyiş nazariyesinden yönetime taşımaya muktedir olmuştur. Safeviler Şia'yı şiar edinen bir devlet kurmak veya askeri siyasi bir harekâta girişmek arzusunda oldukları vakit, bekleyiş nazariyesinin kabul edilebilir ve gerçekçi olmadığını, amaçları önünde ayak bağı oluşturacağını fark ettiler. Böylelikle İsnâ Așeriye mezhebine bağlılıklarını açıklasalar bile imamda -devlet yöneticisi- masumluk ve nassı şart koşan ilahi imamet düşüncesini tam olarak benimsememişlerdir. Devlete pratik karşılığ 1 olan bir fikıh anlayışı gerektiği için, İmamet nazariyesini tarihi bir görüşe çevirerek yumuşattılar ve Emevi, Abbasi ve Osmanlıların yaptığına benzer bir şekilde İmamet'in bütün görevlerini yapmaları konusunda ulemaya izin verdiler ${ }^{46}$. Bu çerçevede Kerekî başta olmak üzere Şeyh Zeynüddin b. Ali el-Amili (ö. 1558) gibi usûlî ulemaya mensup âlimler, devletin kurumsallaşması ve Şiî toplumun bekleyen problemlerine acil çözüm üretmek amaciyla tarikatların karizmatik liderlerine karşıllk Şiî ulemaya karizmatik otorite kazandıracak niyâbet-i âmme düşüncesini etkili ve sistematik bir duruma getirdiler. Niyabet-î âmme doktrininin sistematikleşmesi Safevi Şia'sının

43 Mehmet Çelenk, “Safevîlerin Din Politikası ve İran'ın Şiîleşme Seyri”, Çanakkale Onsekiz Mart Üniversitesi Illahiyat Fakültesi Dergisi, sy. 4, (2014): 21.

44 Bkz. dipnot 31'de belirtildiği üzere Şia'da ulemanın imamın siyasi otoritesini temsil etme noktasında teori Büveyhi'ler döneminde gelişmiştir. Safevi dönemi kadar olmasa da Şii düşünce siyasallaştırılarak, bir devlet politikası haline gelmiştir. Ayrıca bkz. Muharrem Akoğlu, "Büveyhiler'in Mezhebi Eğilimleri/Politikalaları Üzerine", Bilimname 17, (2009/2): 123-138.

45 Çelenk, Iran'da Şî̀liğin Seyri, 155.

46 Çelenk, Iran'da Şiîliğin Seyri, 251. 
kendine mahsus bir tavır geliştirmesini ve imamın gaybetiyle Şiî fikhın içinde bulunduğu çıkmazın aşılmasını sağlamıştı ${ }^{47}$. Böylelikle toplumsalsiyasal konularda hükümler verebilen müçtehitler, daha sonra hiyerarşik bir yapılanmaya giderek merce'iyyet müessesini (Kaçarlar dönemi) ortaya çıkarmıştır. Nitekim Kerekî gibi Usûli ekole mensup ulemanın bu cesur hareketlerine Irak-1 Arab, Körfez-Hicaz gibi Ahbârî ekolün güçlü olduğu bölgelerden önemli eleştiriler gelmiştir. ${ }^{48}$.

\section{Muhakkık el-Kerekî ve İbrahim Katifi; Şiî Ulema Arasında Yaşanan Tartışmalar}

Burada öncelikle Safevi tarihinde devlet-ulema ilişkilerinde önemli bir noktayı temsil eden Şeyh el-Kerekî'yi ele almak gerekmektedir. Safeviler döneminde naîbü'l-imâm olarak anılan en önemli âlim, Muhakkık Kerekî' dir. Kerekî ile birlikte, içtihada karşı çıkan önemli Ahbârî muhalefetine rağmen Usûlî fikhı önemli bir gelişme göstermiştir. Şah İsmail ve Tahmasb'a hizmet eden Kerekî ile birlikte Safeviler, aşırı Şiî fikirlerden uzaklaşıp (Gulâtu'ş-Şi'a) mutedil İsnâ Aşeriye çizgiye girmiştir ${ }^{49}$. Dolay1sıyla Kerekî, Şî̂liğin İran'da yayılmasında önemli bir görev üstlenmiştir. İlk üç halifeye ve önde gelen Sünni ulemaya sövmenin meşru olduğuna dair fetva vermiştir ${ }^{50}$. Sünni ulemayı İran'dan kovmuştur. Ayrıca Camilerin kıblelerinin doğru olmadığını belirterek değiştirilmesini istemiştir ${ }^{51}$. Yukarıda da belirttiğimiz gibi Tahmasb ilan ettiği ferman ile Kerekî’ye naibü'l-imâm sıfatını bahşederek niyâbet-i âmme kavramını fonksiyonel bir hüviyete kavuşturmuştur ${ }^{22}$. Kerekî, "adil bir fakihin, mümkün olan bütün konularda İmam'1 temsil etmesi gerektiğini” belirtmiştir ${ }^{53}$. Böylelikle Şiî ulema siyasi otorite ile birlikte entegre çalışmaya başlamıştır.

\footnotetext{
Uyar, Şî̀ Ulemâ, 119.

Çelenk, "Safevîleri Din Politikası", 21.

Daftary, Şii İslam Tarihi, 109.

el-Kâtib, Şia Siyasal Düşüncenin Gelişimi, 427.

Uyar, Şî̀ Ulemâ, 125.

52 Said Amir Arjomand, Authorityand Political Culture in Shi'ism, (State University of New York Press, 1988), 252-260.

53 Uyar, Şiî Ulemâ, 126. "Şiî usûlü’l fikhında akıl neye hükmederse aynı şekilde şeri'at da ona hükmeder" kaidesi vardır. Çelenk, "Safevîleri Din Politikası", 30.
} 
Kerekî Câmi'u'l-Mekâsıd adlı eserinde Kur'ân, imamların ahbârıla birlikte gelmiş olan sünnet, icma ve akli delillerin İmamî ahkâmın çıkarılabileceği yegâne kaynaklar olduğunu belirtmiştir. Ölü müçtehidin fetvasının taklidinin caiz olmadığını, farz olan taklit için müçtehidin hayatta olması gerektiğini belirtmiştir ${ }^{54}$. Gaybet döneminde Cuma namazının ise fetva şartlarını taşıyan fakih tarafından kılınabileceğini belirtir. Böylelikle fukahanın Cuma namazı kıldırmasına cevaz vermiştir ${ }^{55}$. Nitekim Kerekî kendisinden önceki Şiî ulema tarafından takip edilen pek çok sınırı aşmıştır. Bu ulemaya güç kazandırmakla birlikte Safevi Devleti'nin acil çözüm bekleyen sorunlarının pratik bir şekilde çözümünü sağlamıştır. Fakat Kerekî'nin Safevi Devleti ile bu kadar içli dışlı olması, dönemin Ahbâri ulemasının önemli bir kısmında büyük bir rahatsızlık yaratmıştır. Safevi Şî̂liğiyle ilgili şüpheleri ve Kerekî'nin siyasi olarak bu kadar güç kazanmasının yarattığı rahatsızlık bazı âlimlerin muhalefetine sebep olmuştur. Bu dönemde Ni'metullah Hillî, Emir Gıyâsuddin, Mansur ed-Deşteki eş-Şirazi ve İbrahim Katifi gibi alimler, gaybet döneminde fakihin Cuma namaz1nı kıldırabileceği düşüncesine ve mescitlerin kıblelerinin değiştirilmesine eleştiri getirmişlerdir. Ama en büyük eleştiri Doğu Arabistan kökenli İbrahim Katifî (ö. 1539)'den gelmiştir. Kerekî ve Katifî arasındaki asıl tartı̧̧ma câir (zalim) sultandan gelen haracın kabulü ve Safeviler gibi siyasi bir güçle (gasıp, geçici yönetim) sıkı ilişkiler kurmanın caiz olup olmadığıdır. Katifi, Kerekî'nin heteredoks Safeviler ile yakın ilişkileri, günlük yaşama fazla müdahale etmesi ve aşırı rasyonel tutumuna eleştiri getirmiştir. Katifî, sultandan gelen haraç ve hediyelerin kabulü ile ulemanın Safevi Şahlarını İmam veya meşru yönetici yerine koyduğuna dair endişelerini belirtmiştir ${ }^{56}$. Çünkü bu dönemde Şiî ulemanın büyük bir kesimi halen adil sultan yani Onikinci İmam'ın yönetiminin meşru olduğunu düşünmektedir. Bu yüzden geçici yönetimlerle fazla içli dışlı olmamak kaidesi ile bu yönetimlere meşruiyet kazandırmaktan kaçınmaktaydılar. Katifî ve Kerekî arasındaki tartışma güçlü bir otorite altında ulemanın siyasete dâhil olmasını düşünenler ve onikinci imamın gelmesini bekleyen ulema arasındaki tartışmadır. Fakat devletin Kerekî ve yandaşlarını desteklemesi sonucunda

Uyar, Şî̀ Ulemâ, 128

${ }_{55}$ Uyar, Şî̀ Ulemâ, 128-129. Bkz. Ali b. Hüseyin el-Kerekî, Cami'u'l-Mekâsıd fi Şerhi 'lKavâ'id,

56 Uyar, Şiî Ulema, 133-135. Bkz. İbrahim el-Katîfî, “es-Sirâcü'l-Vehhâc li Def'i 'Icâci Kâti'ati'l-Licâc. 
Katifî gibi siyasi otoriteden uzak durmayı seçen ulema zayıflamıştır. Nitekim Kerekî'nin eserlerinde, Safevilerin beklentileri ile örtüşen pek çok içtihat vardır. Kerekî’ye göre İmam'ın gaybeti döneminde, Müslümanlar hükümdar adına haraç toplayabilir ve ondan hisse alabilirlerdi ${ }^{57}$. Ayrıca İmam'ın gaybetinde Cuma namazı kılabilirlerdi. Bu uygulamaların hepsi Safevi Devleti'ne meşruiyet kazandırmaktaydı. Çelenk'in belirttiği gibi, aksi durumda -ulema devletten uzak durmaya devam etseydi- "devletin hareket alanı daralır, dini/ideolojik programın akim kalması yanında devletin kurumsal yapılanması" da bütünlüğü elde edemezdi58

Kerekî tarafından geliştirilmiş olan İmam'ın genel vekilliği kavramı Safevi dönemi Usûlî ve Ahbârî ekol arasındaki asıl tartışma konusudur. Ahbârî ekolün kesin olarak muhalefetine karş1lık içtihat yolu açık olan Usûlî ekol, İmam'ın yokluğunda müçtehitlere önemli roller vermekte ve onların akli saiklerle toplumsal-siyasal konularda hüküm vermelerine imkân tanımaktaydı. Bu çerçevede adil bir fukaha içtihada başvurmak suretiyle, sadece adil ve masum imamın tasarrufunda olan -doğrudan devlet yönetimi ile bağlantılı olan- cihad ve ganimet taksimi, Cuma namazı kıldırma, kaza ve ceza hükümlerini uygulama, zekat ve humusu toplama ve devlet yönetiminde görev alma konularında yetki sahibi varsayılırdı. Böylelikle ulema, mevcut bekleyiş nazariyesine geliştirdiği bu alternatif nazariye sayesinde "cair" sultanın hükmü altında imamın vekilliği üstlenebiliyorlard ${ }^{59}$. Buna karşılık cihad ve ganimet taksimi, Cuma namazı kıldırma, kaza ve ceza hükümlerini uygulama, zekat ve humusu toplama gibi sadece İmam'a mahsus görülen konular üzerinde gerçekleştirilen tartışmalar aslında tek bir başlı̆̆ açıklamak içindir: İmam'ın yokluğunda ulema vekil olarak toplumsal-siyasal hayatı yönlendiren bu tür görevleri yapabilir mi? Ahbâri ekol bu düşünceyi sakıncalı görmüştür. Onlara göre bekleyiş nazariyesine bağlı kalınmalı ve âlimler ahir zamanda geri dönecek olan imamın yerine -adil bir fakih olsa bile- vekillik iddiasında bulunamayacaktır. "Mehdi'nin sancağından önce dikilen her sancağın sahibi Allah'ın dışında ibadet edilen

\footnotetext{
57 Çelenk, İran'da Şiûliğin Seyri, 287-295.

58 Çelenk, Iran'da Şî̀liğin Seyri, 303. Albert Hourani, “The Safavid Era”, Expectation of The Millenium, Shiism in History, ed. Seyyed Hossein Nasr, (State University of New York Press, 1989), 188; Fettah, “İmâmiyye Şîa'sı”, s. 247-248.

59 el-Kâtib, Şia Siyasal Düşüncenin Gelişimi, s. 464.
} 
bir tağut ${ }^{60}{ }^{\text {tur }}{ }^{\prime 61}$. Bu ifadeden de anlaşılacağ biat etmek, devlet yönetimine dâhil olmak, kendisini yetkili olarak görüp içtihadı, kıyası ve zanni delillerle amel etmeyi haram saymıştır. Böylelikle Ahbârîlik, içtihadı bir kenara koyarak dini konularda sadece peygamberden ve imamlardan gelen kesin haberlerle desteklenmiş bilgiyi kabul etmiştir ${ }^{62}$. Ahbârî ekolün bu tutumu ulemayı toplumsal-siyasal konulardan soyutladığ için devletin gerekli gördüğü konularda siyasi ve dini uygulamalar ortaya koymasının meşruiyetini tartışmaya açmakla birlikte yönetim ve kamusal alanda önemli bir boşluğun ortaya çıkmasına neden olmaktaydı. Usûlî ekolün geliştirmiş olduğu niyâbet-i âmme doktrini, oluşan bu boşluğu doldurmakla birlikte ulemayı bekleyiş nazariyesinden uzaklaştırıp yönetime taşıma imkânı tanımıştır.

Kerekî sonrasında Şiî ulema arasındaki tartışmalar devam etmekle birlikte ulema giderek güç kazanmıştır. Özellikle bu dönemde ulema arasında mutlak içtihadın önem kazanması büyük bir etken olmuştur. Mukaddes Erdebili (ö. 1585) etrafında gelişen tartışmalar neticesinde Zeynüddin Amili tarafindan geliştirilen bu fikir, fikhî hükümlerin elde edilmesinde mutlak içtihadın önemini vurgulamıştır. Mutlak içtihat anlayışının ise Şiî ulemanın güçlenmesinde önemli bir etkisi olmuştur. Bu görüşe göre herhangi bir konuda içtihat kabiliyetinde olan müçtehidin, bunun dişındaki konularda da, potansiyel olarak aynı kabiliyeti taşıdığı farz edilmiştir ${ }^{63}$.

${ }^{60}$ Tağut: put, putlaştırılmış şey, ayartan kötü yola sürükleyen,şeytan gibi anlamlarının yanında haddi aşan, azgınlaşan ve belirlenmiş sınırı geçen her şeye sözlük olarak "tağut” denir. Bkz. Serdar Mutçal1, Arapça-Türkçe Sözlük, (İstanbul: Dağarcık, 1995), 522. Şii siyaset anlayışında ise masum imamların yönetimi dışındaki diğer "câir" ve "geçici" yönetimleri ifade eden bir sözcüktür. Özellikle gayr-i meşru idare olarak anlaşılmaktadır. Bkz. Kaymal, "Şia'da İmamet Meselesi ve Egemenlik”, 180-182, 185-188. Nitekim sözcüğün Şia'da kullanımında farklılıklar bulunmaktadır. Sözcük daha sonra Ahbâriler tarafindan ulemanın imamın yönetme yetkisine el atması içinde kullanılmıştır. el-Kâtip, Şia Siyasal Düşüncenin Gelişimi, 463-64. Bunun yanında İmam Humeyni ise İran'da Şah rejimini câir statüde ele almaktadır. Böylelikle Şah rejimini gayr-i meşru ve tağut mertebesine indirgemektedir. O, Tağut'u yıkmak; bütün İslâm beldelerindeki gayrimeşru siyasal güçleri ve düzenleri (önce İran'da) yıkmak şeklinde tanımlamıştır. Böylelikle Velâyet-i Fakih yönetim şeklinin gerekliliği ve meşruluğunu oluşturmaktadır. Bkz. Bkz. İmam Humeyni, Velâyet-i Fakih: İslam Devleti, İmam Humeyni'nin -ks- Eserlerini Tanzim ve Yayınlama Müessesesi, 175: http://ankara.icro.ir/uploads/islamic_government.pdf

${ }^{61}$ el-Kâtib, Şia Siyasal Düşüncenin Gelişimi, 341.

62 el-Kâtib, Şia Siyasal Düşüncenin Gelişimi, 347.

63 Uyar, Şî̀ Ulemâ, 136. 
$\mathrm{Bu}$ dönemde, dinsel vakıfların yönetiminden ve bütün Safevi ülkesinde Şiî İslâm'ın yayılmasının koordinasyonundan sorumlu sadr makamı yaratılmıştır. Böylelikle Safevi Devleti'nin dini yapısı kurumsallaştı ve İsfahan, Meşhed ve Tebriz gibi büyük kentlerde yetkili şeyhülislamları ve camilerde namaz kıldıran imamları (pişnamaz) oldu. Bu kurumsallaşma Safevi ülkesinde hala dolaşımda olan aşırı düşünceleri denetim altına ald ${ }^{64}$. Böylelikle Safevi Şiî uleması, kendisini Mesih ilan edecek bir gücün veya kendi otoritelerinden daha üstün bir otoritenin ortaya çıkmasını önleyebilme gücüne kavuşmuştur. Dışarıdan gelen ulemanın yaptığ 1 ilk şey Gulâtu'ş-Şi'a'yı ortadan kaldırmak oldu. Safevilerin ulema sınıfını güçlendirmek için din işlerinin büyük çoğunluğunu onların eline temsil etmesindeki amaç, siyasî ve askeri güçlerine ruhaniliğin (ulemanın) gücünü de eklemektir. Böylelikle Safevi Şahları, kendi iktidarlarına meşruiyet sağlayacak her türlü konuda -din, ilim, kültür- fetva almaya muktedir olmuştur. Nitekim Safevi Şahları baştan itibaren vurguladığımız devletin merkezileşme ve kurumsallaşmasını garantilemek adına ulemayı kontrol etmeye ve bürokratik düzeyde örgütlemeye gitmiştir. Örneğin bir bölgeye yerel yönetici tayin edilirken onunla birlikte bir Cuma imamı ile devletin resmi tebligat işini yapmak ve söz konusu imamı kontrol altına almak üzere bir hatip görevlendirilirdi. Çınar'ın belirttiği gibi 'Kerekî ile birlikte Safevî ülkesinde ortaya çıkan Şiî ulema sınıfı, Şah için sadece dini müesseseleştiren ve ülkede Şiî öğretiyi yayan müttefikler değildi. Aynı zamanda Şah kendisi için problem oluşturan Sûfi tarikatlar ve bu tarikatlar içerisinde şekillenen Kızılbaşların nüfuzunu kırmak için de Şiî ulemayı kullanmıştır" ${ }^{65}$. Safevi dönemi Şiî ulema devletten aldıkları güç ile karizmatik bir ulema profili önünde duran en önemli problem olan tarikat ve Sûfi çevreleri bastırma imkânına sahip olmuştur. Şiî ulemanın bu dönemde üzerine fikir yürüttüğü birkaç mesele bulunmaktaydı. Bunlar: Kızılbaşların temsil ettiği mehdîci hareketlerin ve gulat fikirlerin yok edilmesi, halk arasında yaygın olan sûfilliğin/tarikatların bastırılması, Sünnîliğin baskı altına alınması ve İsnâ Aşeriye Şiîliği’nin propagandasını yapmak, şeklinde sıralanabilir. Özellikle 17. yüzyılda devletin tarikat yapısından uzaklaşarak kurumsal kimliğinin oturmaya başlamasıyla birlikte tarikat ve Sûfi kesime karşı reddiyelerde artış görülmüştür. Böylelikle din adamlarına dayalı bir

64 Daftary, Şii İslam Tarihi, 110.

65 Çınar, "Şahlar ve Şiî Ulema", 28. 
devlet modeli güçlenirken devleti yaratan tarikat ve tasavvuf hedef tahtas1na konulmuş̧tur ${ }^{66}$. Tarikatların yapıları ve şeyh mürit ilişkisi usûlî ulemanın sahip olduğu fikıh anlayışına göre ulemanın otoritesine doğrudan bir tehditti. Nitekim tarikatların ortaya koyduğu liderlik anlayışında var olan veli, şeyh, kutub, el-âlimü'l-rabbanî ve er-rüknü'r-râbî şeklindeki sıfatlar ve Hz. Ali'ye dayanan tarikatlarda Oniki İmam'a velayet makamında yapılan vurgu, Şiî ulemanın imamın temsil yetkisi gibi daha karizmatik bir otoriteye bürünmesinin önünde engeldi. Ayrıca tasavvuf ve tarikat üzerinde iktidara yürüyen Safeviler için yeni rakipler yaratma tehlikesi bulunmaktaydı. Bu ikiliği çözmek ve devleti İsnâ Aşeriye Şiîliği'nin fikıh anlayışına göre şekillendirme isteği, tasavvuf ve aşırı fikirlerin silinmesini gerekli kılmıştır. Sonuçta, toplumsal planında yaşanan bu değişim, Şiî ulemanın güç kazanması ve fikhın tasavvufa galip gelmesine neden olmuştur. Tasavvufu ve tarikatları otoritelerine ve hatta Oniki İmam'ın velâyeti ve imametine tehdit-tehlike olarak gören ulema (özellikle Usûlî ekol) bu dönemde yazdıkları risaleler ve yaptıkları baskılarla onları önce devlet yönetiminden sonra sosyal hayattan uzaklaştırmıştır. Devlet ve toplumsal hayatta boşalan yerler bir taraftan devlet idaresinde sadaret ve şeyhülislâmlık gibi kadrolar ihdas ederek, diğer taraftan da zekât ve humus gibi dini gelirlerin ve vakıfların yönetimini kendilerine teslim etmek suretiyle ulemaya verilmiştir ${ }^{67}$.

Şah Abbas (1588-1629)'ın hâkimiyet yılları merkezi otoritenin güçlü olduğu bir dönemdir. Şah Abbas aynı zamanda hem dinin hem de siyasetin liderliğini ve hâmiliğini üstlenmiştir. $\mathrm{O}$, ülkede muhalif sesleri engellediği gibi kendi çevresinde bulunan ulema ve yöneticiler arasındaki anlaşmazliklara da engel olmuştur. Örneğin Lübnan menşeli âlim Şeyh Bahaî ile dönemin diğer meşhur âlimi Mir Damad, dini konularda zıt iki gruba mensup olmalarına rağmen Safevi hanedanlığının meşruiyet kanallarını geliştirmek ve Osmanlılara karşı ideolojik savaşı yürütmek için hükümet ile işbirliği yapmışlardır. Bununla birlikte ikilinin dini konulardaki tartışmaları Şah Abbas'ın himayesinde devam etmiştir. Ancak devlet desteği ve şahın himayesi her iki kesim arasındaki anlaşmazlığın büyümesini engellemiş-

66 Süleyman Gökbulut, "Safevîler Devrinde Şî̂liğin Yayılmasında Tasavvufun Rolü: Tasavvuf Tarihi Açısından Bir Değerlendirme”, Hitit Üniversitesi İlahiyat Fakültesi Dergisi 15, sy. 30, (2016/2): 289.

67 Mazlum Uyar, “Tasavvuftan Teşeyyu'a (İmâmiyye Şiası) Geçiş ve Tasavvufa karşı Alınan Tavır", Akademik Araştırmalar, sy. 3, (1999-2000): 121-139. 
tir. $\mathrm{Bu}$ durumun bir sonucu olarak Safevi uleması nadiren rakibini gözden düşürme firsatı yakalayabilmiştir ${ }^{68}$. Şah Abbas döneminde ön plana çıkan Şeyh Bahâüddin Amilî (d. 1547- ö. 1631) Şiî fikhının oturmasında önemli bir işleve sahiptir. İyi bir şâir, felsefeci ve mistik alanında da güçlü bir alim ve İsfahan okuluna mensup olan Bahâüddin, Isfahan'a Şeyhülislam olarak atanmıştır. Şah Abbas, ondan toplumun günlük ihtiyaçlarına cevap verecek, ilmihal niteliğinde bir eser hazırlamasını istemiştir. Bahâüddin kaleme aldığı Câmi-i Abbâsi isimli eserinde şeriatın emrettiği ve yasakladığ şeyler konusunda, geleneksel Şiî düşüncesine yakın ve devlet otoritesini destekleyen bir düşünce ortaya koyarak, müçtehitlerin toplumsal-siyasal alana daha fazla müdahale etmesi konusunda onları cesaretlendirmiştir ${ }^{69}$.

17. yüzyıl Safevi Devleti'nin zayıflamasıyla Şiî ulema daha fazla ön plana çıkmaya başlamıştır. Aynı zamanda Usûlî ulemaya karşı önemli bir Ahbârî muhalefetinin yükseldiği ve iki karşıt grup arasındaki makasın daha fazla açıldığı gözlenmektedir. Daftary'nin tespit ettiği üzere 17. yüzyılda kadar Usûlî ekol tarafından bastırılan Ahbârî ekol daha fazla görünür olmaya başlamıştır. Özellikle 17. yüzyıl başında Molla Muhammed Emin elEsterabadi (ö. 1624) Fevâidi'l-Medeniyye isimli kitabında Ahbârî tutumu yeniden ele almış ve canlandırmıştır ${ }^{70}$. Esterabadi bizzat içtihat düşüncesine saldırmış, müçtehitleri reddetmiş ve usûlî ulemayı din düşmanı olarak damgalamıştır. Nitekim Esterabadi de klasik Usûli-Ahbâri tartışması olan imamın vekilliği konusu üzerinde durmuş̧tur. Ona göre velayet bir biattir. Ehl-i Beyt rivayet çizgisinden çıkmış olan fakihlerin velayeti kabul edilemez. $\mathrm{O}$, ahbâra atıf yaparak içtihat ve taklit'in haram olduğunu belirtir ${ }^{71}$. 'İmam hadislerinin, Kur'ân'ın görünür, lafzi anlamından, Peygamber hadislerinden ve akıldan önce geldiğine işaret eder. Çünkü imamlar, bu kaynakların ilahi olarak atanmış müfessirleridir" "72. Böylelikle içtihadı ön olana çıkaran akli fikıh esaslarını tekrar hadis temelli bir konuma getirmeye çalışmıştır. Nitekim Esterabadi ve onun gibi düşünen Ahbârîler masum

\footnotetext{
${ }_{68}$ Çınar, "Şahlar ve Şiî Ulema”, 29. Daftary, Şii İslam Tarihi, 110-111.

69 Uyar, Şiî Ulemâ, 137.

70 Daftary, Şii Íslam Tarihi, 114.

71 el-Kâtib, Şia Siyasal Düşüncenin Gelişimi, 493; Robert Gleave, Scripturalist Islam: The History and Doctrines of the Akhbârî Shî'î School, (Boston: Brill, 2007), 6, 177178.

72 Daftary, Şii Íslam Tarihi, 114.
} 
imam dışında siyasi faaliyetleri, imamın yetkilerini üstlenerek yasama ve yürütme işleri ile meşgul olmayı ulemaya haram saymaya devam etmiştir. Esterabadi'nin Ahbârî öğretileri, Muhammed Taki el-Meclisi (ö. 1660) ve Molla Muhsin Feyz-i Kaşani (ö. 1680) gibi önde gelen birçok İmâmî âlim tarafindan benimsenmiştir. İmamlara atfedilen ve İmâmî hadislerin "Kütüb-i Erbaa"sında bulunmayan "güvenilir" hadislerden oluşan bir derleme hazırlayan Lübnanlı el-Hürr el-Amili (ö. 1693) de Ahbârî hadisçiliği savunmuştur $^{73}$. Nitekim Esterabadi'nin düşüncesini devam ettiren el-Fadıl el-Hindi gibi âlimler, Cuma namazında imamlık yapmak için ancak imamın yetkili olduğunu, hiç kimsenin bu mevzuda yetki sahibi olmadığı gibi naiblik yapamayacağını belirtmiştir ${ }^{74}$. Böylelikle İran başta olmak üzere Irak, Lübnan ve Bahreyn'de Ahbârî ekol nispeten güç kazanmıştır ${ }^{75}$.

\section{Safevi Devleti'nin Zayıflaması ve Muhammed Bakır el-Meclisi}

Safevi Devleti'nin sonlarına doğru zayıf şahlar idarede bulunmuş, oluşan otorite açığı Şiî ulema tarafından doldurulmuştur. Safevi ulemasının siyasal ve dinsel hayattaki konumu Muhammed Bakır el-Meclisi (ö. 1699) ile birlikte doruğa ulaşmıştır. İsfahan'da Şeyhülislam olan Meclisi, Şah Süleyman (ö. 1694) ve Sultan Hüseyin (ö. 1713) ile yakın bağlantılar kurmuştur. Şah Hüseyin'in taç giyme törenini yönetmiştir. Daha sonra İsnâ Aşeriye teokrasinin en üst yönetimi olan mollabaşlık makamına atanmış$\mathrm{t}{ }^{76}$. Üretken bir âlim olan Meclisi, Şiî ulema arasında en çok eser veren ve en çok öğrenci yetiştiren âlimlerden biri olarak zikredilmektedir. En meşhur eseri ahbâr alanında yazdığı Bihâru'l-Envâr'dır. Kendisini hâdise adamıştır. Akla dayalı ilimlere fazla itibar etmemiştir. Nitekim Meclisi, Ahbârî ekolüne mensuptur. Meclisi, imamlara ve onlardan gelen ahbâra yeniden itibar kazandırmakla birlikte Şiî ulemanın güçlenmesinde köşe taşlarından biridir. Meclisi'nin mollabaşlık makamına atanması "Şiî bir devlette, ulema sınıfının müesseseleşmesinde, önemli bir merhale olarak"

\footnotetext{
73 Daftary, Şii İslam Tarihi, 114-115; Gleave, Scripturalist Islam, 45-46.

74 el-Kâtib, Şia Siyasal Düşüncenin Gelişimi, 495.

75 Gleave, Scripturalist Islam, 8.

76 Momen, An Introduction to Shi'i, 316-317. Mollabaşlık makamı için bkz. Said A. Arjomand, “The Office of Mulla-bashi in Shi'ite İran”, Studia Islamica 57, (1983): $135-146$.
} 
kabul edilmiştir77. "Şah Hüseyin'i tahta oturtan kişiı" olarak zikredilmesi Meclisi'nin elde ettiği gücü ölçmek açısından önemli bir söylemdir. Meclisi, Şeyhülislam, mollabaşı, Cuma ve cemaat imamlığı gibi hem dünyevi hem de dini görevleri üstlenerek, ulemanın dini ve siyasi alanlardaki etkinliğini artırmıştır. Hayatının son dört yılında İran'ın gerçek yöneticisi olmuştur. Fakat Uyar'ında belirttiği gibi Meclisi'nin en büyük marifeti avam ile kurduğu yakın bağ nedeniyle ileride ulemanın halk desteği ile devlet karşısında bağımsız bir güç olmasının zeminini hazırlamış olmasıdır. $\mathrm{O}$, Kerekî ve diğer ulemaya karşın halk ile yakın bağlar geliştirmiş, Farsça kaleme aldığı risaleler ile halkı kendi yanına çekmiştir. Ahbârî bir akımı temsil etmesine rağmen yaptıkları ileride Usûlî ulemanın güç kazanmasına yaramıştır. Ayrıca Meclisi, imam ve imamzâdelerin türbelerini ziyaret ve Hz. Hüseyin'e yas ile ilgili ritüeli, daha önce görülmedik şekilde yaymıştır. Bunların yanı sıra duâlar, kıssalar, mu'cize, ezan, istihâre, hudud, diyet gibi çok değişik alanlarda, imamların ahbârlarını içeren Farsça risaleler yazmıştır. Meclisi, devletten aldığı destekle odağını üç alana yoğunlaştırmıştır. Birincisi felsefe ve tasavvufun bastırılmasıdır. İkinci olarak İsnâ Aşeriye'nin dogmatik tarafını ön plana çıkaran bir anlayışı hâkim kılmaya çalışmasıdır. Üçüncüsü ise, başta Sünnilik olmak üzere diğer dini grupların toplum hayatından uzaklaştırılmasıdır. Meclisi'nin Şiîliği yaymak için uyguladığı baskının -Sünniler üzerinde- 1722'de Afgan işgaline sebep olduğu iddia edilmektedir. Fakat Meclisi'nin bu dönemde Şiîliği yaymak için yaptıkları, Afganlar ve Nadir Şah gibi Sünni hükümdarların hâkimiyetinde İran'ın Şiî karakterini korumasını sağlamıştır ${ }^{78}$.

Meclisi'nin kelam ve fikha dair görüşleri büyük oranda ahbâra dayanmaktadır. Kesin bir şekilde İmam'dan gelen ahbârın "kafir Yunan'a ait olan zanla" elde edilen bilgiden daha doğru olduğunu belirtmiştir. Fakat Meclisi, gerek Usûlî ekole mensup ulemanın yarattığ değişimlerin siyasal-toplumsal hayata önemli düzeyde yansıdığı bir çevrede yetişmiş olması ve gerek siyasi yönetim ile kurduğu yakın bağlantı nedeniyle, Şiî ulemanın toplumsal-siyasal hayata müdahil olması konusunda Ahbârî ekole mensup diğer ulemaya oranla daha mutedil bir tutuma sahiptir. Cuma namazına dair görüşü ise, vakit namazları kıldırmak için imama veya onun temsilcisine ihtiyacın bir ön koşul olmadığı gibi, Cuma namazının kılınması içinde

77 Uyar, Şî̀ Ulemâ,139.

78 Çelenk, Iran'da Şî̀liğin Seyri, 313-316. 
benzer bir ön koşul ileri sürmeye gerek olmadığı yönündedir. Ona göre, Cuma namazını kıldıran kişinin ise müçtehit olmasına gerek yoktur, namazla ilgili genel kuralları bilen adil bir kişi olması yeterlidir. Aynı şekilde Şahların otoritesine tam bir bağlılı̆̆ın gerekli olduğunu belirtmiştir. Bu konudaki görüşleri ile Sünni fikhına yaklaşmıştır: yöneticinin zalim ve cair olmas1 durumunda bile, onlara itaat edilmesi gerekir ${ }^{79}$. Uyar'ın tespit ettiği üzere, Meclisi'nin başta bulunan siyasi otoriteye pragmatik yaklaş1mı, "aynı zamanda ulemanın gücüne işaret etmekte ve ulemanın hiyerarşik yapılanmasını sağlayan bir merhale"dir. Çünkü siyasi otorite tarafindan da resmen kabul edilen ulema gücü, "dünyevi otoritenin meşruiyetini temin edici veya belirleyici bir vasıf” kazanmıştır. Bu düşünceler sayesinde Meclisi, siyasi otoritenin din üzerindeki gücünü azaltarak, ikisi arasında bir ayrıma gitmiştir ${ }^{80}$. Böylelikle siyasi otoritenin desteğini daha fazla arkasına alan ulema, sonraki süreçte daha da güçlenerek ayrı bir güç odağı olarak siyasi otoritenin karşısında yerini almıştır.

Yukarıda belirtildiği gibi Şiî ulema siyasi boşluğu ve zayıflığ çok iyi bir şekilde kullanmasını bilmiştir. Ulemanın gücü, Safevi hanedanının zayıf olduğu Şah Hüseyin döneminde Meclisi ile zirveye tırmanması tesadüf değildir. Şah İsmail ve Şah I. Abbas gibi kudretli şahların varlığında Meclisi'nin böyle etkili olması pek mümkün olmazdı. Otorite boşluğu ve devam eden kargaşa ile birlikte sürekli değişen hanedanlıklara rağmen ulemanın gücü İran'da hep artmıştır. 1724 yılında Safevi Devleti'nin yıkılmas1 (fiili, resmi olarak 1736) üzerine başlayan anarşi ortamı, siyasi ve dini kurumların birbirinden kopmasına neden olmuştur. Merkezi yönetimin etkisinin olmadığ1 18. yüzyıl boyunca ulema, yerel yönetimlerin, yargıçların, yasa koyucuların ve bunun gibi birçok şeyin işlevini bizzat üstlenmiştir. Zira Safevi Devleti'nin yıkılışı özerklik yönündeki gizli Şî̂ iddiaların ön plana çıkmasına da imkân vermiştir ${ }^{81}$. Nitekim 18. yüzyılda İsfahanlı Muhammed Bakır Bihbehani (ö. 1793) ile birlikte tekrar güç kazanan Usûlî ulema bağımsız bir otorite olarak siyasi otoritenin karşısına çıkmıştır. Kaçarlar dönemine ulaşıldığında, toplumun dini idaresi tamamıyla ulemanın tasarrufuna geçmiş, içtihat anlayışında yaşanan gelişme müçtehit-mukal-

79 Uyar, Şî̀ Ulemâ, 144.

80 Uyar, Şî̀ Ulemâ, 146.

81 Lapidus, İslam Toplumlart Tarihi 1, 412; Elise Perry, “The Rise of Shi' ism in Iran”, Cross-Section: The Bruce Hall Academic Journal 6, (2010): 129-131. 
lit arasındaki ilişkiyi de sağlam temellere oturtmuştur. Neticede Kaçar Hanedanlığı'nın zayıf hâkimiyeti altında Şiî ulema arasında merci-i taklit kurumu ihdas edilecektir. Siyasi olarak tam bir hâkimiyeti olmasa da merci-i taklit ${ }^{82}$, dini otoritenin bir müçtehidin elinde toplanmasına neden olmuştur. Buda velayet-i fakih müessesesinin bir prototipi niteliğindedir. Kaçar Hanedanı'nın soyunu Hz. Ali'ye dayandırmak gibi bir iddiasının olmayışı, İmam'ın temsil yetkisi konusunda ulemanın daha cesur davranmasını sağlamıştır. Bu vasıflar artık ulemaya devredilmiştir. Nitekim Şah'ın kendisi de mukallit olmakla birlikte Şah'ın otoritesi, ulemanın otoritesine hizmet eder duruma gelmiştir. Özellikle Kaçar döneminde devletin bazı yanlış politikaları halkı siyasi otoriteden uzaklaştırarak ulemaya yaklaştırmış ve böylelikle ulema, halkı istediği şekilde yönlendirebilme kudretini elde etmiştir. Nitekim halkın şikâyetlerinin tam olarak ulaşabileceği alternatif bir muhalefet mercii olmaması, halkın din dış1 -siyasi, toplumsal- konularda da şikâyetlerini ulemaya sunmasına neden olmuştur ${ }^{83}$. Bu da Kaçar Hanedanı ve ulema arasında sürekli bir çatışma doğurmuştur. Fakat bütün hanedanlıklar yıkılıp gitmesine rağmen Şiî ulemanın Safevi döneminde devlet dini olarak elde etmeye başladığı güç, Kaçarlar döneminde hiyerarşik bir yapıya dönüşmüş ve onları 1979 'da rakipsiz iktidara taşımışıır ${ }^{84}$. Aslında Şia, teoride sunulanın tam tersini pratiğe dökerek bir

82 “19. yüzyı1 İran’ında ulemanın hiyerarşik bir müçtehitler sınıfına dönüşmesidir. F1kıh usullerine ilişkin bilgileri temelinde seçilen bir grup vasıflı alimin içtihat uygulamasına, bağlayıcı kararlar almasına izin verildi. Aynı zamanda sıradan Oniki İmamcılar, merci-i taklit "üstün örnek" ya da "taklit kaynağı" olarak tanımlanan vasıflı müçtehidi takip edecekti. Usûlî elkolün zaferi, Oniki İmamcı Şiî cemaati taklit etmeye mecbur olan "mukallitler" ve içtihat oluşturma vasfina sahip "müçtehitler" olarak ikiye böldü. Merci-i taklit'in seçimi üstün derecede bilgi ve dindarlığa bağlıydı. Merci-i taklit ölünce yerine yenisi seçilirdi. Çünkü sadece yaşayan bir müçtehidin kararları taklit edilebilir ve bağlayıcıdır. Örneğin Ferâidü'l-usûl eserinin sahibi Şeyh Murtaza Ensari (ö. 1864) yalnızca İran'da değil, Irak, Arap toprakları, Hindistan'da -neredeyse bütün İmâmî cemaatin- merci-i taklit olarak kabul edilmiştir”. Daftary, Şii İslam Tarihi, 117118.

83 Mazlum Uyar, "Velayet-i Fakih'in Ortaya Çıkışı ve Değerlendirilmesi", Dini Araştırmalar 2, sy. 6 (Ocak-Nisan 2000): 78-79.

84 Perry, “The Rise of Shi' ism”, 121. Nitekim Humeyni'nin Velayet-i Fakih düşüncesini oluştururken usûlî ekole mensup, el-Hurrü'l-Amili'nin Vesailu's Şia, Kerekî'nin Câmi'u'l-Mekâsıd ve Ahbârî olmasına rağmen düşünceleri usûlîliğe yakın olan Muhammed Bakır Meclisi'nin Biharu'l-Envar gibi eserlere atıflar yapmıştır. Özellikle de Kaçarlar dönemi usûlî ekolü güçlendirmiş ve ulemanın daha fazla güç elde etmesini savunan Molla Ahmed Naraki (ö.1829) ve "sınırsız merciyett-i taklit" düșüncesini savunan Şeyh Murtaza el-Ensari (ö. 1864) gibi alimlerin eserlerinden önemli oranda 
zafere ulaşmıştır. Çelenk'in belirttiği gibi; "Şîa tarihi baştan sona devletin meşruiyet esasları ve ulemanın devlete göre konumu merkezli tartışmalar ile geçmiş; teorik çerçevede mehdî-yi muntazar'ın gelişine kadarki fiilî devletler gayrı meşru ve başındakiler de câir olarak görülmüş ve ulemanın bu sistemlerle diyalogu tasvip edilmemiştir. Pratik Şîa tarihi ise, denilebilir ki bunun tamamen dışında seyretmiştir. Büveyhîler dönemi, İlhanlılar dönemi, Safevîler ve Kaçarlar dönemi pratiği, Şîa teorik devlet-ulema ilişkileri nazariyesinin dişında bir çizgide seyretmiştir. Şîa tarihi, teorik esaslar ve pratik farklılıklar üzerine bina edilmiştir"»5. Fakat teorinin pratiğe uydurulmaya çalışıldığ 1 dönem, Safevi çağ 1 olmuştur. Özellikle ulemay1 neredeyse siyaset dışı bir konuma iten Ahbârî ekole karşı Usûlî ekolün içtihat ve müçtehitlerin konumuna dair ortaya koyduğu yeni yorum, ulemay1 Şiî toplumun vazgeçilmez lideri konumuna yükseltmiştir ${ }^{86}$.

\section{Sonuç}

1501 tarihinde Şah İsmail'in Şiîliği devletin resmi mezhebi olarak ilan etmesi, İran ve Şiî tarihi açısından bir dönüm noktası olmuştur. 1514 Çaldıran yenilgisi sonrasında Şah İsmail devletin kurumsallaşması gerektiğini anlamıştır. Kendisini yönetime taşıyan Kızılbaş ve tarikat çevrelerinin devlet yönetimindeki eksikliğini fark etmiştir. Ayrıca bu çevrelerin yeni bir lider bulup Safevi Hanedanı'na karşı yeni bir güç oluşturabileceklerinin farkındır. Bu nedenle hem devleti hem de Şiî mezhebini kurumsallaştırıp güçlendirerek hanedanının sürekliliğini güvence altına almaya çalışmıştır. Bu çerçevede Cebel-i Amil ve diğer bölgelerden Şiî fikhına hakim olan ulema getirtmiştir. Dışarıdan gelen ulema hem devletin kurumsallaşmasına yardımcı olmuş hem de Şiî ulemanın güçlenmesini sağlamıştır. Özellikle Kerekî gibi Usulî ekole mensup ulemalar, Gaib İmam'ın görevlerini üstlenerek yönetime dâhil olmuşlardır. Normal şartlarda Şiî ulemanın câir gördüğü devlet yönetiminden uzak durma ve bekleyiş nazariyesine uyma prensiplerini terk ederek, Safevi devletinin pratik ihtiyaçları çerçevesinde İmam'ın vekilliğini savunmuşlardır. Devletten aldıkları güç sayesinde hem

faydalanmıştır. Ayrıntılı bilgi için bkz. Fettah, “İmâmiyye Şîa’sı”, 249-251; Uyar, "Velayet-i Fakih'in Ortaya Çıkışı", 79, 87.

85 Çelenk, Iran'da Şiîliğin Seyri, 317.

86 Uyar, "Velayet-i Fakih'in Ortaya Çıkışı", 81. 
konumlarını sağlamlaştırmış hem de Şiîliğin İran'da yayılmasında önemli bir işlev görmüşlerdir. Fakat bu süreç bir anda gerçekleşmemiş, Usûli ve Ahbârî ekole mensup ulema arasındaki tartışmalar çerçevesinde ve Şiî ulemanın otoritesini zayıflatabilecek Sûfi çevrelerin ve tarikatların gücünün ortadan kaldırılmasıyla mümkün olmuştur. Fakat Şah I. Abbas sonrasında Safevi tahtına geçen Şahların zayıflığından faydalanarak daha fazla güç elde eden ulema, Kaçar Hanedanlığ 1 dönemindeki karmaşanın sağladığ güç boşluğunda devletin karşısında yeni bir güç merkezi olarak konumlanmıştır. Bu koşullarda ortaya çıkan merce-i taklit müessesesi, Humeyni'nin karizmatik liderliğinde velâyet-i fakih yönetim -müessesesi- anlayışının oluşmasının temellerini atmıştır.

\section{Kaynakça}

Algar, Hamid. "İran (III. Kültür ve Medeniyet)". DİA. 22: 409-413. Ankara: TDV Yay., 2000.

Arjomand, Said A. "The Office of Mulla-bashi in Shi' ite İran." Studia Islamica, 57, (1983): 135-146.

Arjomand, Said Amir. Authority and Political Culture in Shi'ism. State University of New York Press, 1988.

Corbin, H. "Şiîlikte Velâyet Kavramı." çev. Sabri Hizmetli. AÜIFD 27, (1983): 717-726.

Çelenk, Mehmet. "Safevîler Döneminin Şiî-Sünni İlişkileri Üzerinde Etkisi.” Mezhep Araştırmaları, 6/2 (Güz 2013): 63-85.

Çelenk, Mehmet. “Safevîleri Din Politikası ve İran'ın Şiîleşme Seyri." Çanakkale Onsekiz Mart Üniversitesi Illahiyat Fakültesi Dergisi, sy. 4 (2014): 7-35.

Çelenk, Mehmet. 16-17. Yüzyıllarda İran'da Şiîliğin Seyri. Bursa: Emin Yayınları, 2016.

Çınar, Gülay Karadağ. "Safevi Devleti’nde Otoritenin Temsilcisi Şahlar ve Şiî Ulemayla İlişkileri.” Irran Çalışmaları Dergisi 1, sy. 1 (2017): 11-51.

Daftary, Farhad. Şii İslam Tarihi. çev. Ahmet Fethi. İstanbul: Alfa Tarih, 2016. 
el-Kâtib, Ahmed. Şiada Siyasal Düşüncenin Gelişimi: Şûrâdan Velayet-i Fakîhe. Ankara: Otto Yayınları, 2016.

Fettah, İrfan Abdulhamid. "İmâmiyye Şîa'sında Velâyet-i Fakih, Tarihi Arka Plan”, çev. Seyit Bahcıvan. Marife, sy. 2 (Güz 2009): 243-258.

Fığlalı, Ethem Rûhi. İmâmiyye Şîası. İstanbul: Ağaç Kitabevi Yayınları, 2008.

Gleave, Robert, Scripturalist Islam: The History and Doctrines of the Akhbârî Shî'î School. Boston: Brill, 2007.

Gökbulut, Süleyman. "Safevîler Devrinde Şiîliğin Yayılmasında Tasavvufun Rolü: Tasavvuf Tarihi Açısından Bir Değerlendirme." Hitit Üniversitesi İlahiyat Fakültesi Dergisi 15, sy. 30 (2016/2): 269-297.

Gündüz, Tufan. "Safeviler". DİA. 35:451-457. Ankara: TDV Yayınlar1, 2008.

Gündüz, Tufan, “Tahmasb”. DİA. 39:413-415. Ankata: TDV Yayınlar1, 2010.

Güner, Ahmet. "Mâverdî’nin Hilafet Kuramının Tarihsel Arkaplanına Bir Bakış (II).” D.E.Ü. Illahiyat Fakültesi Dergisi, sy. 17 (İzmir, 2003): 227252.

Hourani, Albert. "Cebel-i Amil'den İran'a”, çev. Habib Kartaloğlu. Usûl İslâm Araştırmaları, sy. 23 (Ocak-Haziran 2015): 213-226.

Hourani, Albert. "The Safavid Era", Expectation of The Millenium, Shiism in History, ed. Seyyed Hossein Nasr, State University of New York Press, 1989.

İmam Humeyni. Velâyet-i Fakih: İslam Devleti. İmam Humeyni'nin -ksEserlerini Tanzim ve Yayınlama Müessesesi: http:/ankara.icro.ir/uploads/ islamic_government.pdf

Kallek, Cengiz. "Mâverdî”. DİA. 28: 180-186. Ankara: TDV Yayınları, 2003.

Kallek, Cengiz. "Sânî Muhakkık-1 Kerekî". DİA. 25:280-282. Ankara: TDV Yayınları, 2002.

Kaymal, Cansu. "Şia'da İmamet Meselesi ve Egemenlik." Bilecik Şeyh Edebali Üniversitesi Sosyal Bilimler Enstitüsü Dergisi 2, sy. 1, (Haziran2017): 172-195. 
Keddie, Nikki R. "The Roots of the Ulema's Power in Modern Iran." Studia Islamica, no. 29 (1969): 31-53.

Kevserani, Vacih. Osmanlı ve Safevîlerde Din-Devlet İlişkisi, çev. Muhlis Canyürek. İstanbul: Denge Yayınları, 1992.

Küpeli, Özer. Osmanlı-Safevi Münasebetleri. İstanbul: Yeditepe Yayınlar1, 2014.

Lapidus, Ira M. İslâm Topluları Tarihi: 19. Yüzyıldan Günümüze. 2. İstanbul: İletişim Yayınları, 2010.

Lapidus, Ira M. İslam Toplumları Tarihi: Hz. Muhammed'den 19. Yüzylla.1. İstanbul: İletişim, 2013.

Momen, Moojan. An Introductionto Shi'i Islam. New York: Yale University Press, 1985.

Mutçalı, Serdar. Arapça-Türkçe Sözlük. İstanbul, Dağarcık, 1995.

Onat, Hasan. "Şiî İmâmet Nazariyesi." AÜIFD 32, (1992): 89-110.

Perry, Elise. "The Rise of Shi' ism in Iran." Cross-Section: The Bruce Hall Academic Journal 6, (2010): 121-136.

Salih, Subhi. İslam Kurumları. çev. İbrahim Sarmış. Ankara: Fecr Yayınevi, 1999.

Sümer, Faruk. Safevi Devletinin Kuruluşu ve Gelişmesinde Anadolu Türklerinin Rolü. Ankara: Güven Matbaası, 1976.

Taflıŏlu, Serkan. "İran İslam Cumhuriyeti'nde Egemenlik ve Meşrûiyet Kaynağ1 'Velâyet-i Fakih'." Ankara Üniversitesi SBF Dergisi 68, no. 3 (2013): 95-112.

Tarik, Ramazan. "Şia'da Usulîliğin Doğuşu ve Şeyh Müfis." Mezhep Araşttrmalart 7, sy. 1 (Bahar 2014): 251-259.

Teber, Ömer Faruk. “XVI. Yüzyılda Kızılbaşlık Farklılaşması.” Doktora Tezi, Ankara Üniversitesi, 2005.

Uyar, Mazlum. "Tasavvuftan Teşeyyu'a (İmâmiyye Şiası) Geçiş ve Tasavvufa karşı Alınan Tavır.” Akademik Araştırmalar, sy. 3 (1999-2000): 121139.

Uyar, Mazlum. "Velayet-i Fakih'in Ortaya Çıkışı ve Değerlendirilmesi." Dini Araştırmalar 2, sy. 6 (Ocak-Nisan 2000): 77-98. 
Uyar, Mazlum. Şî̀ Ulemânın Otoritesinin Temelleri. İstanbul: Kaknüs Yayınları, 2004.

Üstün, İsmail Safa. "Velâyet-i Fakih". DIA. 43:19-22. Ankara: TDV Yayınları, 2013.

Yazıc1, Tahsin. "Cüneyd-i Safevi”. DİA. 8:123-124. Ankara: TDV Yayınlar1, 1993. 